\title{
AN EVALUATION OF THE STRUCTURE OF ENERGY CONSUMPTION IN EDUCATIONAL BUILDINGS IN POLAND AFTER THERMAL RETROFITTING
}

Anna Życzyńska ${ }^{1}$; Zbigniew Suchorab ${ }^{2 *}$; Grzegorz Dyś' ${ }^{1}$ Jakub Čurpek ${ }^{3}$, Miroslav Čekon $^{4}$

\begin{abstract}
The paper presents the structure and indices of the annual energy consumption in educational buildings subject to comprehensive thermal retrofitting. Seven buildings were analyzed; the energy consumption for heating and ventilation, hot water preparation, and built-in lighting was analyzed in each of them and, in the case of one structure, also cooling. The indices of the usable, final, and primary energy consumption were analyzed. The values calculated were compared to the requirements of the energy standards in force in Poland. The percentage shares of the above-mentioned energy demands of each of the buildings investigated are given in the total energy performance. Within the investigation, we evaluated the shares of the particular building services in the total energy consumption and determined that even after the thermal retrofitting, the energy demands for heating together with lighting are still the most significant compared to the other demands.
\end{abstract}

Address

1 Dept. of Conservation of Built Heritage, Faculty of Civil Engineering and Architecture, Lublin University of Technology, Lublin, Poland

2 Dept. of Water Supply and Wastewater Disposal, Faculty of Environmental Engineering, Lublin University of Technology, Lublin, Poland

3 Dept. of Physics, Faculty of Civil Engineering, Slovak University of Technology, Bratislava, Slovakia

4 Institute of Building Structures, Faculty of Civil Engineering, Brno University of Technology, Brno, Czechia

* Corresponding author: z.suchorab@pollub.pl

\section{Key words}

- Energy consumption;

- Thermal retrofitting;

- Usable energy;

- Final energy;

- Primary energy.

\section{INTRODUCTION}

Each building in use requires an external supply or the on-site production of energy from various sources. The amount of energy or its carrier depends on the type of energy demands of the building (Życzyńska, 2009; Piccardo et al., 2020). This is mainly due to the building's functions and the balance necessary to maintain an appropriate level of thermal comfort during its lifetime (De Rosa et al., 2014; Dodoo et al., 2010; El-Darwish and Gomaa, 2017; Ramírez-Villegas et al., 2019). In the European countries, the recast Energy Performance of Building Directive (EPBD) sets out the standards for new and renovated buildings across Europe that are adopted in the building regulations and codes at the national level of each member state. In general, there is agreement in Europe to use the intensity indicators of end uses and primary energy uses to reflect the depletion of fossil fuels and proportional $\mathrm{CO}_{2}$ emissions.

The cost-effective transformation of existing buildings is generally expected. For instance, in France, the heating regulation (RT 2012) sets out a mean level of primary energy consumption in terms of central heating, cooling, lighting, domestic hot water production, and auxiliary systems. It also aims to reduce the energy use of existing buildings. In the Czech Republic, the current regulation is defined in terms of Act No. 406/2000 and the newest legal ordinance No. 264/2020 Coll. The ordinance and standards set limits for assessments of energy performance and for renovations. The minimum energy performance requirements should be based on cost-optimal levels that are compared with a reference building, which is a hypothetical copy of the new or renovated building and which performs exactly as stated in the legislation (the ordinance) and Czech standards related to the thermal protection of buildings. These requirements implement primary energy factors from non-renewable sources. In Slovakia, Directive 2010/31/EU was implemented by Act No. 300/2012 Coll., and introduced primary energy as a global energy performance indicator. The directive amended Act No. 555/2005 Coll. and also established definitions of technical, functional, and economic feasibility for the minimum requirements of the energy performance of an existing building after it undergoes major renovations aiming to meet the same criteria as new buildings. In Austria, the energy savings and heat retention 
of both residential and non-residential buildings are ensured by the OIB Guidelines developed by the Austrian Institute of Construction Engineering. They mainly deal with requirements for heating/cooling, domestic hot water (DHW) demands, and maximum U-values for new and existing (in the case of renovations) buildings. In Belgium, regulations for the energy performance of buildings are enacted by regional competences. The responsibility for implementing the EPBD resides with three regions: the Brussels Capital Region, the Flemish Region, and the Walloon Region. The Brussels Air, Climate and Energy Code (COBRACE) integrates the energy performance of buildings into a broader legal, environmental, and energy framework. The Flemish Energy Agenca (VEA) is responsible for the energy performance requirements in the Flemish Region and has implemented requirements for Technical Building Systems (TBS). In the Walloon Region, the determination of optimal energy performance levels in relation to costs was set out in a study called Co-ZEB, which was launched by the Department of Energy and Sustainable Buildings. These three regions use a single, jointly developed software tool, and the calculation methodology is almost identical for all the regions. In Germany, the Energy Saving Ordinance ("Energieeinsparverordnung" or "EnEV") specifies the minimum energy performance requirements, whereas the Renewable Energies Heating Act sets out renewable energy quotas for new buildings and refurbished public buildings. The Deutsches Institut für Normung (DIN) standards serve as a compulsory calculation methodology. In Denmark, the implementation of the EPBD is ensured by the Danish Energy Agency (DEA). The energy efficiency requirements for buildings are determined by Danish Building Regulations 2018 (BR2018), which operate with six different categories of construction projects that differ in relation to the energy requirements. In Poland, legal acts which clearly define the types of building energy demands that should be analyzed when determining energy performance and drawing up a building's energy certificate (Dz.U. 2008 No. 201 p. 1238; Dz.U. 2009 No. 43 p. 347; Dz.U. 2015 p. 376) have been in force since 2008.

The final effect of a building's energy analysis is a determination of the annual non-renewable primary energy index (PE) and a comparison between the results obtained and the requirements resulting from the national regulations (Act. No 300/2012 Coll. - Slovak Republic; (BR18) - Danish Building Regulations, and Ordinance No. 264/2020 Coll. - Czech Republic). According to the European legislation, the calculation of primary energy also includes renewable sources. Obtaining the PE index is preceded by calculations of the usable energy demand index (UE) and final energy (FE) indices of a building (Życzyńska et al., 2020a, 2020b) which can be mainly achieved by the reduction of energy consumption. In the case of the existing objects, this goal could be achieved by the thermo-modernization of the building partitions and equipment. This article concerns the issue of heat consumption for heating purposes after a comprehensive retrofitting of nine educational buildings (two kindergartens and seven schools). The UE index determines a building's energy demands without any recognition of the types and efficiency of the building services. The FE index takes into account the types and efficiency of these systems, and the PE index additionally considers the type of fuel used and the type of energy. The FE and PE indices additionally cover the demands for the so-called auxiliary electric energy required for the technical systems considered (Piotrowska and Borchert, 2017; Tomczak and Kinash, 2016) adapted to the requirements of the National Fund for Environmental Protection and Water Management ("NF40" standard.

Based on the Regulations of Polish Ministry (Dz.U. 2015 p. 376), the following four groups can be distinguished among the buildings subject to energy assessments: (1) residential buildings not equipped with a cooling system; (2) residential buildings equipped with a cooling system; (3) buildings other than residential buildings not equipped with a cooling system, and (4) buildings that are not residential build- ings equipped with a cooling system. In the first group, the needs of the buildings related to their heating and ventilation systems as well as hot water preparation are considered; in the second group the same rules are as in the first with additional energy needs related to cooling; in the third group the same rules are as in the first and, in addition, the needs related to the energy necessary for built-in lighting; and in the fourth group, the same rules are as in the third, and, in addition, energy needs related to cooling.

Tab. 1 Types of building structures for energy assessments (Dz.U. 2015 p. 376)

\begin{tabular}{|c|c|c|c|c|c|}
\hline No & Type of buildings & Heating & $\begin{array}{c}\text { Hot } \\
\text { water }\end{array}$ & Cooling & Lighting \\
\hline 1 & $\begin{array}{c}\text { Residential buildings } \\
\text { without a cooling system }\end{array}$ & + & + & - & - \\
\hline 2 & $\begin{array}{c}\text { Residential buildings with } \\
\text { a cooling system }\end{array}$ & + & + & + & - \\
\hline 3 & $\begin{array}{c}\text { Non-residential buildings } \\
\text { without a cooling system }\end{array}$ & + & + & - & + \\
\hline 4 & $\begin{array}{c}\text { Non-residential buildings } \\
\text { with a cooling system }\end{array}$ & + & + & + & + \\
\hline
\end{tabular}

As presented in Table 1, the four types of needs (heating, hot water production, cooling and lighting) can be distinguished in the structure of the energy consumption. The shares of energy consumption by the particular building services vary and depend on the building standards and the types and quality of those services (De Rosa et al., 2014; Wang and Holmberg, 2015).

In each group, it is necessary to determine the level of the demands for auxiliary electricity for technical systems. Each building energy certificate contains UE, FE, PE indices expressed in $\mathrm{kWh} /$ $\left(\mathrm{m}^{2} \cdot \mathrm{a}\right)$. In turn, each one of them can be divided into the type of energy demands of the building and their percentage share in the total building energy demands, but are set out separately for usable, final, and non-renewable primary energy. Based on these data, it is possible to arrive at conclusions about the structure of the building's energy demands and the type of fuel. The analysis of this structure permits determining the most important components in the overall energy balance of the building ( $\mathrm{Li}$ et al., 2020). On the other hand, together with the analysis of the technical characteristics of the building, it should permit identifying certain energy-poor elements in it, which in turn would allow for the proposed measures that could lead to the improvement of energy efficiency. Based on the values of the final energy indices and information on fuel, it is possible to determine the unit value of the carbon dioxide emissions $\left(\mathrm{E}_{\mathrm{CO} 2}\right)$, which are most often expressed in $\mathrm{CO}_{2} /\left(\mathrm{m}^{2} \cdot \mathrm{a}\right)$ tons (Wasti and Zaidi, 2020; Zhao et al., 2018). The UE index can be used to assess the energy quality of the building envelope, while the FE index can be used for the energy quality of the building, i.e., the building envelope and its equipment with heating, ventilation, cooling, and hot water systems.

The value of the PE index and carbon dioxide emissions is often used to assess the ecological quality of a building and its impact on the environment (Oh et al., 2017). A detailed analysis of the indices makes it possible to describe the relationship between them. The examples show that buildings with low FE ratios do not always have low PE values. On the other hand, there are examples of buildings characterized by quite high FE indexes, which proves that a building's energy quality is not very high, but that the use of renewable sources of energy, e.g., biomass, can cause a significant reduction in the PE index value. When assessing a building, it is worth considering the possibility of using cogeneration systems and technological systems 


\section{No. 1}
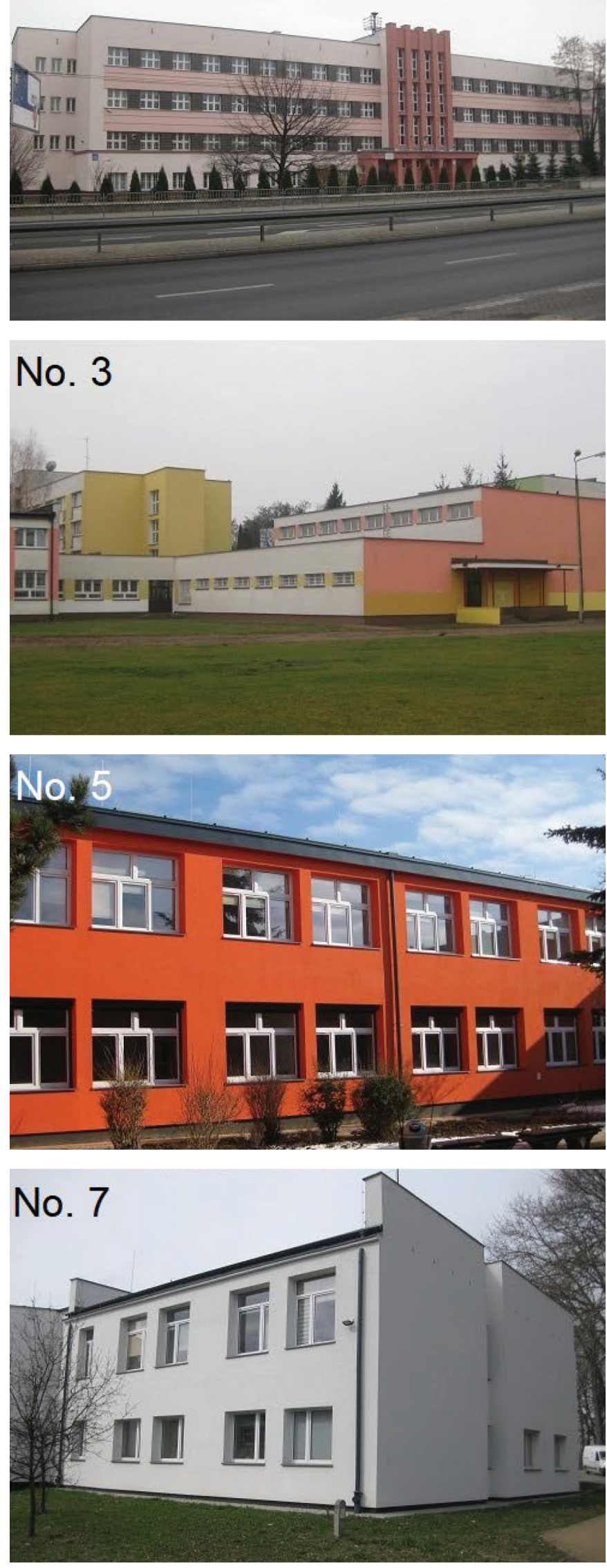

Fig. 1 Photographs of the buildings investigated
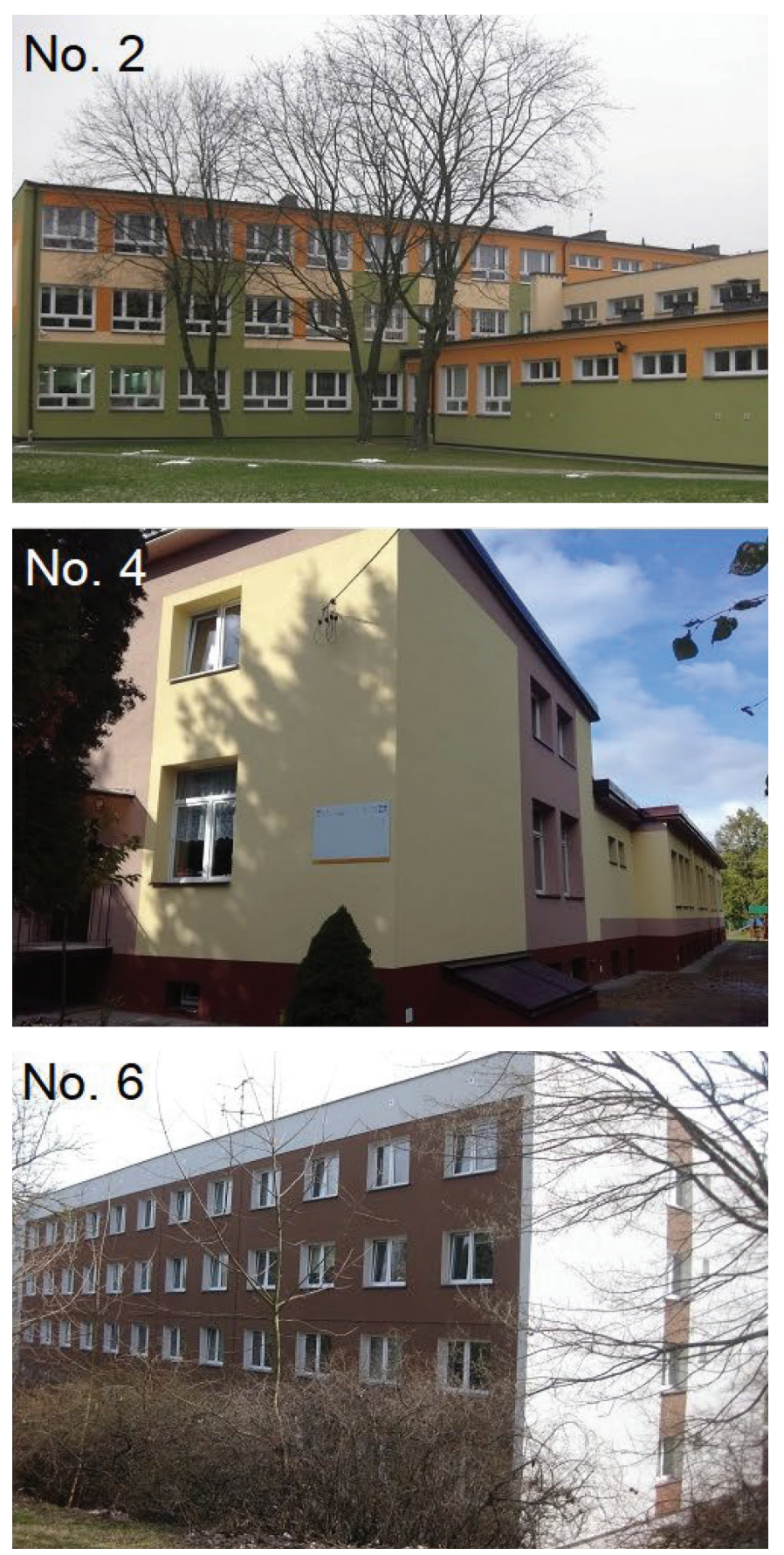

using renewable energy sources. Therefore, depending on the quality assessment criteria applied for the energy or an ecological building, appropriate indices of the annual energy demand should be analyzed.

\section{MATERIALS AND METHODS}

In this research study seven educational buildings (Fig. 1) were investigated under the energy performance indices after their thermal retrofitting procedure. The first stage of the investigation was a calculation of the energy certificates according to the requirements defined by the national standards and regulations (Dz.U. 2013 p. 45; Dz.U. 2017 p. 22). The following energy indices were calculated for each structure: the usable energy demand index (UE), final energy consumption index (FE), and primary energy consumption index (PE). The $\mathrm{PE}$ values were additionally compared with the $\mathrm{PE}_{0}$ boundary values for each type of building. 
Tab. 2 Basic parameters of the buildings investigated

\begin{tabular}{|c|c|c|c|c|c|c|c|c|c|c|}
\hline \multirow{2}{*}{ No. } & \multirow{2}{*}{ Function } & \multirow{2}{*}{\begin{tabular}{|c|} 
Constr. \\
year
\end{tabular}} & \multirow{2}{*}{\begin{tabular}{|c|} 
Retrof. \\
year
\end{tabular}} & \multirow{2}{*}{$\begin{array}{c}\text { Heated } \\
\text { usable area }\end{array}$} & \multirow{2}{*}{$\begin{array}{l}\text { Heated } \\
\text { volume }\end{array}$} & \multicolumn{5}{|c|}{ Overall heat transfer coefficient of building envelopes after retrofitting (U) } \\
\hline & & & & & & External walls & Roofs, flat-roofs & Ground floor & Windows & Ext. doors \\
\hline- & - & - & - & $\mathrm{m}^{2}$ & $\mathrm{~m}^{3}$ & \multicolumn{5}{|c|}{$\mathrm{W} /\left(\mathrm{m}^{2} \cdot \mathrm{K}\right)$} \\
\hline 1 & School & 1937 & 2014 & 4435.2 & 15367.5 & $\begin{array}{c}0.238 ; 0.237 \\
0.233\end{array}$ & $\begin{array}{l}0.215 ; 0.198 \\
0.196 ; 0.195\end{array}$ & $0.536 ; 0.483$ & 1.8 & 1.8 \\
\hline 2 & School & 1973 & 2014 & 3239.0 & 10866.3 & $0.238 ; 0.237$ & $0.214 ; 0.198$ & $0.608 ; 0.485$ & 1.8 & 1.8 \\
\hline 3 & School & 1998 & 2014 & 11915.0 & 38072.1 & $\begin{array}{l}0.247 ; 0.246 \\
0.245 ; 0.238 \\
0.229 ; 0.214\end{array}$ & $\begin{array}{c}0.223 ; 0.222 ; 0.217 \\
0.213 ; 0.208\end{array}$ & $0.548 ; 0.536$ & 1.8 & 1.8 \\
\hline 4 & School & 1968 & 2018 & 778.1 & 2205.1 & $0.19 ; 0.18$ & 0.15 & 0.74 & $1.8 ; 0.9$ & 1.3 \\
\hline 5 & University & 1989 & 2018 & 1408.5 & 4507.2 & $0.20 ; 0.19$ & 0.15 & 0.52 & 1.8 & $1.8 ; 1.3$ \\
\hline 6 & University & 1969 & 2019 & 2426.4 & 6327.8 & $0.23 ; 0.20 ; 0.16$ & 0.16 & 0.87 & $1.8 ; 0.9$ & $2.0 ; 1.3$ \\
\hline 7 & University & 1988 & 2019 & 2847.0 & 8912.2 & $0.19 ; 0.18$ & $0.15 ; 0.14$ & $0.51 ; 0.33$ & $1.8 ; 0.9$ & $1.8 ; 1.3$ \\
\hline
\end{tabular}

Together with the energy indices for each building, the environmental impact of the amount of $\mathrm{CO}_{2}\left(\mathrm{E}_{\mathrm{CO} 2}\right)$ emitted by the structure into the atmosphere was evaluated.

As mentioned above, the structures investigated were educational buildings located inside and around the city of Lublin, Poland, which is situated in the third climatic zone (winter design temperature $=$ $-20^{\circ} \mathrm{C}$ ); its number of degree-days equals $3825.2($ day $\cdot \mathrm{K}) / \mathrm{a}$. What is important for the investigation is that all of the structures belong to the same meteorological station; the effect of the climate on the energy performance of all of the buildings is the same. All the buildings are located between urban buildings that are similar in height but at a considerable distance from the educational structures investigated. All of the buildings are freestanding and glazed on all sides, so that their spatial orientation does not significantly affect their energy performance. Four of the buildings investigated are schools (primary or secondary schools), and three of them are university faculty buildings. The oldest structure was built before the Second World War; three of them were built in the 1960s - 1970s. Two buildings come from the late 1980s and, lastly, one school was built at the end of the 20th century. Details of all the buildings are presented in Table 2.

All the buildings are similarly used with a comparable number of working hours and days per week. Additionally, Building No. 3 is supported with a dining room, but none of the buildings is supported by a kitchen for food preparation. Three structures were thermally retrofitted in 2014, and four of them were retrofitted in 2018 and 2019. This fact influenced the methodology of the energy certificates and, accordingly, the index values and calculations. In the cases of Structure Nos. 1-3, the certificates were calculated using the Regulations of the Polish Ministry (Dz.U. 2013 p. 45); in the cases of Building Nos. 4-7 all the calculations were conducted according to the requirements of the Regulation of the Polish Ministry (Dz.U. 2017 p. 22). As can be seen in Table 1, the values of the overall heat transfer coefficients (U-value) for the external envelopes are similar; in the case of the buildings retrofitted in
2014 , they achieved values between $0.2-0.25 \mathrm{~W} /\left(\mathrm{m}^{2} \cdot \mathrm{K}\right)$, depending on the particular barrier. For the structures modernized in 2018-2019, the $\mathrm{U}$-values are smaller and reach $0.16-0.23 \mathrm{~W} /\left(\mathrm{m}^{2} \cdot \mathrm{K}\right)$ for the walls and $0.14-0.16 \mathrm{~W} /\left(\mathrm{m}^{2} \cdot \mathrm{K}\right)$ for the roofs/flat roofs. Also, the ground floors are characterized by $\mathrm{U}$ coefficient values that on average are equal to about $0.5 \mathrm{~W} /\left(\mathrm{m}^{2} \cdot \mathrm{K}\right)$; only in the case of University Building (No. 6) which was retrofitted in 2019 , this value was significantly higher, i.e., $0.87 \mathrm{~W} /$ $\left(\mathrm{m}^{2} \cdot \mathrm{K}\right)$. The overall U-values of the windows and doors were different, because in the case of some structures, the old elements had been replaced by better ones before the thermal retrofitting. For purposes of comparison, Table 3 presents the boundary values of the overall heat transfer coefficients in the period when the retrofitting was conducted.

When comparing Tables 2 and 3, it can be seen that some of the partitions do not meet the requirements, e.g., the previously mentioned floors, because the floors with finishing layers in good technical condition were not disassembled and renovated. Also, the windows and doors in some buildings had been replaced several years before the thermal modernization, so that before the entry of the new boundary U-value requirements, they had met the previous requirements. It was therefore not justifiable to replace them from an economic point of view.

During the modernization, all the structures also had their energy supply systems retrofitted. Table 4 presents the details of the heating and electrical energy supply systems of the particular buildings.

As seen in Table 4, the average seasonal total efficiency coefficients of the building services are calculated as a product of the seasonal efficiencies of the heat generation, distribution, accumulation, adjustment, and utilization according to the Regulations of the Polish Ministry (Dz.U. 2013 p. 45).

As can also be seen in Table 4, the heat and electricity supply are similar in most cases, but what is worth mentioning here is that the energy supply of School (No. 4) is significantly different from the others. First of all, the heat supply is covered by the school's own biomass boiler, and the hot water production is covered by electricity. Addition-

Tab. 3 Maximal values of the heat transfer coefficients of the particular building envelopes according to Dz.U. 2013 p. 926

\begin{tabular}{|c|c|c|c|c|c|c|}
\hline \multirow{2}{*}{ Lp. } & \multirow{2}{*}{ Year } & \multicolumn{5}{|c|}{ Boundary value of overall heat transfer coefficient $\mathrm{W} /\left(\mathrm{m}^{2} \cdot \mathrm{K}\right)$} \\
\cline { 3 - 7 } & & External walls & Roofs, flat-roofs & Ground floor & Windows & External doors \\
\hline 1 & 2014 & 0.25 & 0.20 & 0.30 & 1.30 & 1.70 \\
\hline 2 & 2018 & 0.23 & 0.18 & 0.30 & 1.10 & 1.50 \\
\hline 3 & 2019 & 0.20 & 0.15 & 0.30 & 0.90 & 1.30 \\
\hline
\end{tabular}


Tab. 4 Details of the energy supply systems and building services of the structures investigated

\begin{tabular}{|c|c|c|c|c|c|c|c|c|c|}
\hline \multirow{2}{*}{ No. } & \multicolumn{2}{|c|}{ Heat source } & \multicolumn{2}{c|}{ Electricity } & \multicolumn{2}{c|}{$\begin{array}{c}\text { Total efficiency coefficient } \\
\text { of technical system }\end{array}$} & \multicolumn{2}{c|}{${\text { Primary energy input } \mathrm{w}_{\mathrm{i}}}^{2}$} \\
\cline { 2 - 10 } & Heating & Hot water & Source & Lighting type & Heating & Hot water & Heating & Hot water & Electricity \\
\hline 1 & $\begin{array}{c}\text { Heat distribution } \\
\text { system }\end{array}$ & $\begin{array}{c}\text { Heat distribution } \\
\text { system }\end{array}$ & Energy network & Traditional & 0.812 & 0.728 & 0.8 & 0.8 & 3.0 \\
\hline 2 & $\begin{array}{c}\text { Heat distribution } \\
\text { system }\end{array}$ & $\begin{array}{c}\text { Heat distribution } \\
\text { system }\end{array}$ & Energy network & Traditional & 0.795 & 0.728 & 0.8 & 0.8 & 3.0 \\
\hline 3 & $\begin{array}{c}\text { Heat distribution } \\
\text { system }\end{array}$ & $\begin{array}{c}\text { Heat distribution } \\
\text { system }\end{array}$ & Energy network & Traditional & 0.812 & 0.485 & 0.8 & 0.8 & 3.0 \\
\hline 5 & $\begin{array}{c}\text { Biomass boiler } \\
\text { Heat distribution } \\
\text { system }\end{array}$ & $\begin{array}{c}\text { Energy network distribution } \\
\text { system }\end{array}$ & Energy network & $\begin{array}{c}\text { Eluorescent } \\
\text { lamp + LED }\end{array}$ & 0.744 & 0.990 & 0.2 & 3.0 & 3.0 \\
\hline 7 & $\begin{array}{c}\text { Heat distribution } \\
\text { system }\end{array}$ & $\begin{array}{c}\text { Heat distribution } \\
\text { system }\end{array}$ & Energy network & LED & 0.745 & 0.546 & 0.8 & 0.8 & 3.0 \\
\hline system & $\begin{array}{c}\text { Heat distribution } \\
\text { system }\end{array}$ & Energy network & LED & 0.812 & 0.546 & 0.8 & 0.8 & 3.0 \\
\hline
\end{tabular}

ally, one of the university buildings (No. 5) is additionally supported with a photovoltaic (PV) system. Together with the details of the energy supply systems, the total efficiency coefficients of the heating systems and hot water production are presented. It is worth mentioning that in the case of the heating, all the coefficients of efficiencies are similar with values between $0.744-0.812(-)$. In the case of the hot water production, the differences are higher, i.e., between 0.485 and 0.728 (-). Only for Building No. 4 is the efficiency coefficient nearly equal to 1.0 (due to the system of energy supply - electricity applied).

The last columns of Table 4 present the primary energy input values $\left(\mathrm{w}_{\mathrm{i}}\right)$. The non-renewable primary energy input value is connected with the production and supply of energy to the technical systems. It is a coefficient that shows the effect of the energy carriers on the environment. The $\mathrm{w}_{\mathrm{i}}$ values in Table 4 depend on the type of energy supply; thus, except for Building No. 4, all the inputs are equal to 0.8 . In the case of Building No. 4 , the $\mathrm{w}_{\mathrm{i}}$ factor value for heating only equals 0.2 (because of the biomass boiler used for the heat supply) and the high $\mathrm{w}_{\mathrm{i}}$ value for hot water production is 3.0 (due to applying electricity for the hot water production).

\section{RESULTS AND DISCUSSION}

The energy indices evaluated for each structure investigated are presented in graphic form on the bar diagram presented in Fig. 2.

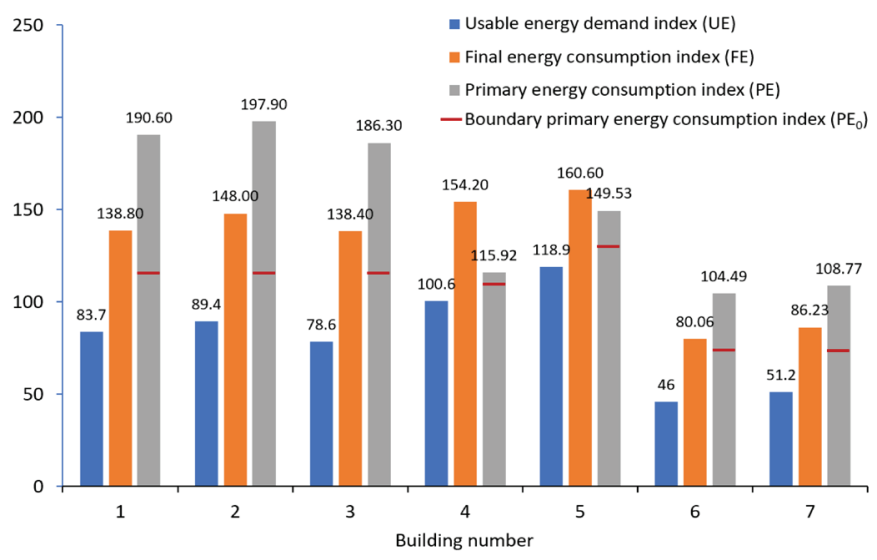

Fig. 2 Energy indices evaluated for all the educational buildings investigated
The diagram (Fig. 2) above presents the calculated values of the energy indices based on the energy certificates issued after the thermal retrofitting of the buildings. The blue color bars show the values of the usable energy demand index (UE), which depend on the quality of the external envelopes. Those values are the lowest and do not consider other parameters of the buildings such as the quality of the energy systems or power sources. The values of the final energy consumption index (FE) are represented by orange bars and in all the cases are higher than the blue ones. Finally, the grey bars show the values of the primary energy consumption index (PE), which also represents the environmental impact of the buildings. The PE values depend not only on the quality of the building envelope and the efficiency of the power systems but also the sources of the energy powering all the systems.

It can be seen that the UE index values are the smallest, i.e., about $50\left(\mathrm{kWh} / \mathrm{m}^{2} \cdot \mathrm{a}\right.$ ), in the cases of the structures retrofitted in 2019 (Nos. 6 and 7). This is a consequence of the better thermo-insulation parameters of the external envelopes, which improved the energy properties of the structures. The schools retrofitted in 2014 (Nos. 1-3) are characterized by inferior thermal insulation parameters of the external envelopes and the substandard quality of the external doors and windows. The efficiencies of the power supply systems are comparable for all the structures investigated; thus, the final energy consumption index (FE) consumption in each case is proportional to the UE indices. Finally, in most cases, the PE index values are higher than the FE; only in Building Nos. 4 and 5 are the PE index values smaller than the FE. In the case of Building No. 4, the reason for the low value was the different type of heat supply based on the biomass boiler, which has a small value of primary energy input, i.e., $\mathrm{w}_{\mathrm{i}}=0.2$. For Structure No. 5 , the decrease in the PE index can be explained by the utilization of a photovoltaic system (PV) for an additional power supply to the building.

Additionally, Fig. 2 presents the boundary value of the annual primary energy consumption index $\left(\mathrm{PE}_{0}\right)$. These values are represented by the red line drawn on the grey bars. Those values are a reference for evaluating the energy efficiency of the buildings. They are limited by the Regulations of the Polish Ministry (Dz.U. 2013 p. 926) concerning the requirements for the buildings. It ought to be underscored that these boundary values are better for an evaluation of newly constructed buildings, not retrofitted ones; they are presented here for comparative reasons. In the case of the structures retrofitted in 2014 (Nos. 1-3), the $\mathrm{PE}_{0}$ boundary values are equal to $115 \mathrm{kWh} /\left(\mathrm{m}^{2} \cdot \mathrm{a}\right)$; in the case of the structures retrofitted in 2018 , they are $110 \mathrm{kWh} /\left(\mathrm{m}^{2} \cdot \mathrm{a}\right)$ 
for Building No. 4 and $127.33 \mathrm{kWh} /\left(\mathrm{m}^{2} \cdot \mathrm{a}\right)$ for Building No. 5 (due to the additional energy consumption for the cooling system). In the case of the Structure Nos. 6 and 7 retrofitted in 2019, the $\mathrm{PE}_{0}$ boundary value was equal to $70 \mathrm{kWh} /\left(\mathrm{m}^{2} \cdot \mathrm{a}\right)$. It should be noted that in all the cases, the PE values exceed the $\mathrm{PE}_{0}$ reference values. Only in the case of the Structure No. 5 is the $\mathrm{PE}_{0}$ value slightly exceeded. This ought to be interpreted as being due to a different source of energy (the biomass boiler) rather than cogeneration (the heat distribution system), which is more environmentally friendly. Finally, it is interesting that the structures retrofitted in 2019, despite exceeding the current requirements, would fulfill the $\mathrm{PE}_{0}$ requirements for the newly constructed buildings in previous years.

In Table Nos. 5-7, more detailed values of the UE, FE and PE indices separated into heating $\left(\mathrm{UE}_{\mathrm{H}}, \mathrm{FE}_{\mathrm{H}}\right.$ and $\left.\mathrm{PE}_{\mathrm{H}}\right)$, hot water production $\left(\mathrm{UE}_{\mathrm{w}}, \mathrm{FE}_{\mathrm{W}}\right.$ and $\left.\mathrm{PE}_{\mathrm{w}}\right)$, and cooling $\left(\mathrm{UE}_{\mathrm{C}}, \mathrm{FE}_{\mathrm{C}}\right.$ and $\left.\mathrm{PE}_{\mathrm{C}}\right)$ and lighting $\left(\mathrm{FE}_{\mathrm{L}}\right.$ and $\left.\mathrm{PE}_{\mathrm{L}}\right)$ are presented. The additional columns present the shares of the particular types of energy usage.

Tab. 5 Usable energy demand indices, depending on the energy usage

\begin{tabular}{|c|c|c|c|c|c|c|}
\hline No. & $\mathrm{UE}_{\mathrm{H}}$ & $\mathrm{UE}_{\mathrm{W}}$ & $\mathrm{UE}_{\mathrm{C}}$ & $\mathrm{UE}_{\mathrm{H}}$ & $\mathrm{UE}_{\mathrm{w}}$ & $\mathrm{UE}_{\mathrm{C}}$ \\
\hline- & \multicolumn{3}{|c|}{$\mathrm{kWh} /\left(\mathrm{m}^{2} \cdot \mathrm{a}\right)$} & \multicolumn{3}{c|}{ Share (\%) } \\
\hline 1 & 75.00 & 8.60 & 0.00 & 89.7 & 10.3 & 0.0 \\
\hline 2 & 80.70 & 8.60 & 0.00 & 90.3 & 9.7 & 0.0 \\
\hline 3 & 69.40 & 9.20 & 0.00 & 88.3 & 11.7 & 0.0 \\
\hline 4 & 92.20 & 8.40 & 0.00 & 91.7 & 8.3 & 0.0 \\
\hline 5 & 92.90 & 8.40 & 17.60 & 78.1 & 7.1 & 14.8 \\
\hline 6 & 37.60 & 8.40 & 0.00 & 81.7 & 18.3 & 0.0 \\
\hline 7 & 42.80 & 8.40 & 0.00 & 83.6 & 16.4 & 0.0 \\
\hline
\end{tabular}

Using the data presented in Table Nos. 5-7, the shares of the particular building services in the total energy consumption of the buildings can be evaluated. Firstly, it ought to be noted that in the case of all the buildings, about $80-90 \%$ of the usable energy consumption mainly comes from the heating system (the average value of all the structures: $86.2 \%$ ). The usable energy consumption that covers hot water production amounts to $11.7 \%$. Cooling was applied only in one case (Building No. 5), which had a usable energy consumption share equal to $14.8 \%$.

An evaluation of the structure of the final energy consumption calls for different observations. Together with the building structure, it is also loaded with energy system efficiencies and electrical energy consumption for lighting. First, it is significant that the share of the lighting is about $20 \%$ of the total final energy consumption (except for Building No. 5, which is supplied with a PV system) which causes a decrease in the other shares. That is why the average share of the final energy consumption for heating is equal to $68.5 \%$ (significantly lower than the reference usable energy consumption of $86.2 \%$ ). The shares of the final energy consumption for hot water production and cooling are similar to the reference shares of the usable energy consumption $(5.5-19.6 \%)$ for hot water and zero for cooling. Taking into consideration Building No. 5, it must be stated that the final energy consumption shares for cooling are smaller than the usable energy consumption for cooling (only 3.0\%). Also, in the case of Building No. 5, the final energy consumption share for lighting is smaller than the other structures and equals $7.9 \%$, which can be explained by the application of LED lighting sources plus the PV system.

The most important index determining the environmental effects of a building is the annual primary energy consumption index (PE). What is important is that the value of this parameter depends on two factors, i.e., the final energy consumption and source of energy, which determine the value of the primary energy input $\left(\mathrm{w}_{\mathrm{j}}\right)$. In Table 2 , it can be seen that in the case of a central heating system supplied from a

Tab. 6 Final energy consumption indices according to the particular building services

\begin{tabular}{|c|c|c|c|c|c|c|c|c|c|}
\hline No. & $\mathrm{FE}_{\mathrm{H}}$ & $\mathrm{FE}_{\mathrm{W}}$ & $\mathrm{FE}_{\mathrm{C}}$ & $\mathrm{FE}_{\mathrm{L}}$ & $\mathrm{FE}_{\mathrm{H}}$ & \multicolumn{2}{|c|}{$\mathrm{FE}_{\mathrm{W}}$} & $\mathrm{FE}_{\mathrm{C}}$ & $\mathrm{FE}_{\mathrm{L}}$ \\
\hline- & \multicolumn{6}{|c|}{$\mathrm{kWh} /\left(\mathrm{m}^{2} \cdot \mathrm{a}\right)$} & \multicolumn{4}{|c|}{ Share $(\%)$} \\
\hline 1 & 92.20 & 11.80 & 0.00 & 34.90 & 66.4 & 8.5 & 0.0 & 25.1 \\
\hline 2 & 101.40 & 11.80 & 0.00 & 34.90 & 68.5 & 8.0 & 0.0 & 23.5 \\
\hline 3 & 85.30 & 18.30 & 0.00 & 34.90 & 61.6 & 13.2 & 0.0 & 25.2 \\
\hline 4 & 125.10 & 8.50 & 0.00 & 20.60 & 81.1 & 5.5 & 0.0 & 13.4 \\
\hline 5 & 127.30 & 15.70 & 4.82 & 12.78 & 79.3 & 9.8 & 3.0 & 7.9 \\
\hline 6 & 47.76 & 15.70 & 0.00 & 16.60 & 59.7 & 19.6 & 0.0 & 20.3 \\
\hline 7 & 54.23 & 15.70 & 0.00 & 16.30 & 62.9 & 18.2 & 0.0 & 18.9 \\
\hline
\end{tabular}

Tab. 7 Primary energy consumption indices according to the particular building services

\begin{tabular}{|c|c|c|c|c|c|c|c|c|c|}
\hline No. & $\mathrm{PE}_{\mathrm{H}}$ & $\mathrm{PE}_{\mathrm{W}}$ & $\mathrm{PE}_{\mathrm{C}}$ & $\mathrm{PE}_{\mathrm{L}}$ & $\mathrm{PE}_{\mathrm{H}}$ & \multicolumn{2}{c|}{$\mathrm{PE}_{\mathrm{W}}$} & $\mathrm{PE}_{\mathrm{C}}$ & $\mathrm{PE}_{\mathrm{L}}$ \\
\hline- & \multicolumn{3}{|c|}{$\mathrm{kWh} /\left(\mathrm{m}^{2} \cdot \mathrm{a}\right)$} & \multicolumn{4}{|c|}{ Share $(\%)$} \\
\hline 1 & 76.10 & 9.90 & 0.00 & 104.60 & 39.9 & 5.2 & 0.0 & 54.9 \\
\hline 2 & 83.40 & 9.90 & 0.00 & 104.60 & 42.1 & 5.0 & 0.0 & 52.8 \\
\hline 3 & 70.60 & 11.10 & 0.00 & 104.60 & 37.9 & 6.0 & 0.0 & 56.1 \\
\hline 4 & 28.63 & 25.49 & 0.00 & 61.80 & 24.7 & 22.0 & 0.0 & 53.3 \\
\hline 5 & 103.57 & 12.75 & 14.46 & 18.75 & 69.3 & 8.5 & 9.7 & 12.5 \\
\hline 6 & 41.49 & 13.20 & 0.00 & 49.80 & 39.7 & 12.6 & 0.0 & 47.7 \\
\hline 7 & 46.67 & 13.20 & 0.00 & 48.90 & 42.9 & 12.1 & 45.0 & 45.0 \\
\hline
\end{tabular}


heat distribution system (cogeneration), the $\mathrm{w}_{\mathrm{i}}$ values equal 0.8 , except for Building No. 4 , which is powered by a biomass boiler $\left(\mathrm{w}_{\mathrm{i}}\right.$ $=0.2$ ). A similar situation is observed in the case of the hot water production with the $\mathrm{w}_{\mathrm{i}}$ factors equal to 0.8 , but they are 3.0 in the case of Building No. 4 (supplied with electric energy for hot water production). In all the cases it is significant that the $\mathrm{w}_{\mathrm{i}}$ factors for electricity are equal to 3.0 , which completely changes the structure of the energy consumption in these objects. What is important is that the shares of primary energy consumption are significantly decreased (by about 35\%) compared to the final energy consumption shares and are only equal to $42.4 \%$ on average. The shares of the primary energy consumption for hot water production are similar to the shares of the final energy consumption or slightly lower. The decreases in the above-mentioned shares are mainly caused by the increased value of the shares for electricity consumption (except for Building No. 5, which is additionally powered by a PV system). The shares of the primary energy consumption are higher than $45 \%$ or even $50 \%$ of the total primary energy consumption.

The energy certificates additionally evaluated the environmental impact of the particular educational facilities on the environment as a result of their carbon dioxide emissions into the atmosphere. The data relating to this investigation are presented in Table 8 .

Tab. 8 Carbon dioxide emissions $\left(E_{\mathrm{CO}_{2}}\right)$ calculated for each structure investigated

\begin{tabular}{|c|c|c|}
\hline No. & Year of retrofitting & $\mathrm{E}_{\mathrm{CO}_{2}}$ \\
\hline- & - & tons $\mathrm{CO}_{2} /\left(\mathrm{m}^{2} \cdot \mathrm{a}\right)$ \\
\hline 1 & 2014 & 0.063 \\
\hline 2 & 2014 & 0.066 \\
\hline 3 & 2014 & 0.062 \\
\hline 4 & 2018 & 0.030 \\
\hline 5 & 2018 & 0.050 \\
\hline 6 & 2019 & 0.040 \\
\hline 7 & 2019 & 0.040 \\
\hline
\end{tabular}

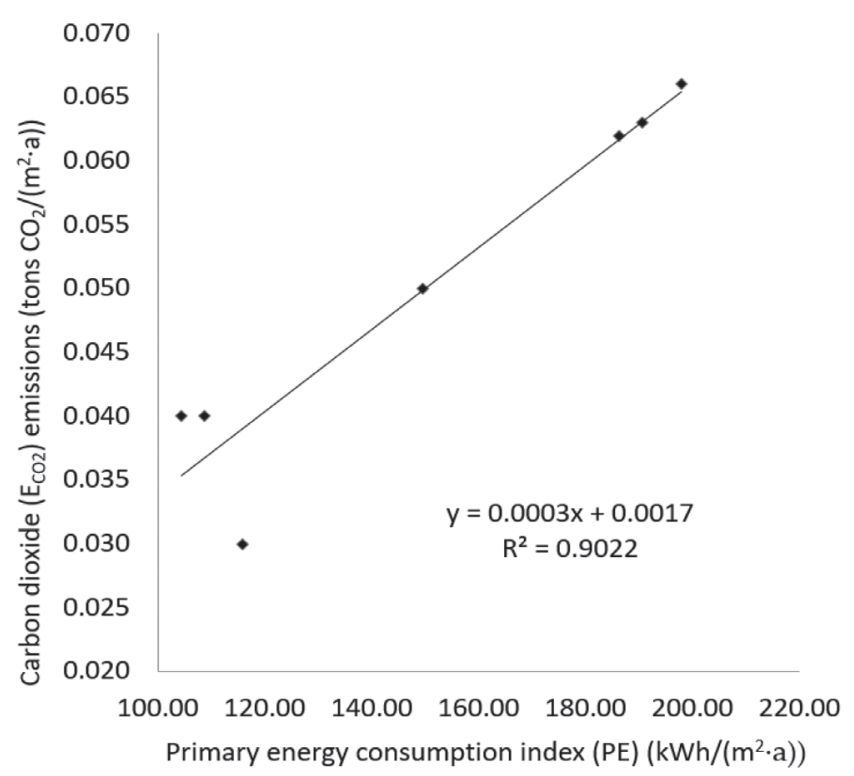

Fig. 3 Dependence between the primary energy consumption index and carbon dioxide emissions from the educational facilities investigated
It ought to be underscored here that the structures retrofitted in 2019 are characterized by the smallest values of $\mathrm{CO}_{2}$ emissions into the atmosphere. Also, it is worth mentioning that the carbon dioxide emissions are correlated with the primary energy consumption index (PE) that is presented in Fig. 3.

As can be seen, the structures with PE index values below 120 emit the lowest amount of carbon dioxide into the atmosphere. Lower emission values were observed in the case of the buildings retrofitted in 2019 with the highest renovation standards and utilizing LED lighting, i.e., Building Nos. 6 and 7. Despite higher PE values, Building No. 4 emits the lowest amount of carbon dioxide, which is a consequence of utilizing another source of energy (biomass) and fluorescent lamps instead of traditional bulbs. Structures with higher values of the PE indices emit proportionally higher amounts of $\mathrm{E}_{\mathrm{CO} 2}$ into the atmosphere. The dependence between the PE index value and $\mathrm{CO}_{2}$ emissions is linear, which confirms the value of the coefficient of determination $\mathrm{R}^{2}$ $=0.9$, especially when a similar source of energy is used.

\section{CONCLUSIONS}

Based on the energy certificates calculated for the seven educational structures investigated and the comprehensive studies of the energy consumption structure, the following conclusions can be drawn on the basis of the studies and calculations conducted:

- The buildings that have been recently retrofitted have a smaller environmental impact compared to the structures modernized in earlier periods, when considering only the performance of the building and energy demands for heating and other systems, such as hot water production, cooling and lighting.

- Despite the comprehensive thermal retrofitting of the buildings and significant reductions in the overall heat transfer coefficients, the share in the total balance of the buildings' energy consumption for heating is significant and exceeds $40 \%$.

- The share of the energy demands for hot water production in the educational buildings is small (about 10\%); therefore, it does not constitute a potential modernization and is not a key element in the search for measures leading to the improvement of the energy efficiency of these facilities.

- The share of energy consumption for lighting in the educational buildings is the highest (about 50\%), so it is worth looking for energy-efficient solutions in this area.

- The use of PV allows for a significant reduction (up to $12.5 \%$ ) of the share of lighting in the energy consumption structure and is thus an improvement in the PE indices.

Finally, it should be underlined that in the case of the thermal retrofitting of educational-type buildings, improving the thermal parameters of their external envelopes becomes ineffective after reaching a reasonable level of the U-values limited by the regulations. From the point of view of the environmental impact of these buildings due to exploitation, it is more reasonable to find improvements in building services and sources of energy. The results obtained that show the structure of the energy consumption can be used for comparison with actual heat consumption readouts of other educational buildings, which would constitute a more complete analysis of the energy management of a building.

\section{Acknowledgement}

This research was supported by the Ministry of Science and Higher Education in Poland within the statutory research of scientific units under subvention for science programs (FN-61/ILT/2019, FN-70/IŚ/2019), the Scientific Grant Agency of the Ministry of Education, Science, Research and Sport of the Slovak Republic, VEGA Project No. 1/0680/20 and by the Czech Science Foundation, Project No. GA 20-00630S. 


\section{REFERENCES}

De Rosa, M., Bianco, V., Scarpa, F., Tagliafico, L.A., 2014. Heating and cooling building energy demand evaluation; a simplified model and a modified degree days approach. Applied Energy 128, 217-229. https://doi.org/10.1016/j.apenergy.2014.04.067

Dodoo, A., Gustavsson, L., Sathre, R., 2010. Life cycle primary energy implication of retrofitting a wood-framed apartment building to passive house standard. Resources, Conservation and Recycling 54, 1152-1160. https://doi.org/10.1016/j.resconrec.2010.03.010

El-Darwish, I., Gomaa, M., 2017. Retrofitting strategy for building envelopes to achieve energy efficiency. Alexandria Engineering Journal 56, 579-589. https://doi.org/10.1016/j.aej.2017.05.011

Li, B., You, L., Zheng, M., Wang, Y., Wang, Z., 2020. Energy consumption pattern and indoor thermal environment of residential building in rural China. Energy and Built Environment 1, 327 336. https://doi.org/10.1016/j.enbenv.2020.04.004

Oh, B.K., Choi, S.W., Park, H.S., 2017. Influence of variations in CO 2 emission data upon environmental impact of building construction. Journal of Cleaner Production 140, 1194-1203. https:// doi.org/10.1016/j.jclepro.2016.10.041

Piccardo, C., Dodoo, A., Gustavsson, L., Tettey, U.Y.A., 2020. Retrofitting with different building materials: Life-cycle primary energy implications. Energy 192, 116648. https://doi.org/10.1016/j. energy.2019.116648

Piotrowska, E., Borchert, A., 2017. Energy consumption of buildings depends on the daylight. E3S Web Conf. 14, 01029. https:// doi.org/10.1051/e3sconf/20171401029

Ramírez-Villegas, R., Eriksson, O., Olofsson, T., 2019. Life Cycle Assessment of Building Renovation Measures-Trade-off between Building Materials and Energy. Energies 12, 344. https:// doi.org/10.3390/en12030344

Tomczak, K., Kinash, O., 2016. Assessment of the Validity of Investing in Energy-Efficient Single-Family Construction in Poland - Case Study. Archives of Civil Engineering 62, 119-138. https:// doi.org/10.1515/ace-2015-0101

Wang, Q., Holmberg, S., 2015. Combined Retrofitting with Low Temperature Heating and Ventilation Energy Savings. Energy Procedia 78, 1081-1086. https://doi.org/10.1016/j.egypro.2015.11.055

Wasti, S.K.A., Zaidi, S.W., 2020. An empirical investigation between $\mathrm{CO} 2$ emission, energy consumption, trade liberalization and economic growth: A case of Kuwait. Journal of Building Engineering 28, 101104. https://doi.org/10.1016/j.jobe.2019.101104

Zhao, W., Cao, Y., Miao, B., Wang, K., Wei, Y.-M., 2018. Impacts of shifting China's final energy consumption to electricity on CO2 emission reduction. Energy Economics 71, 359-369. https:// doi.org/10.1016/j.eneco.2018.03.004

Życzyńska, A., 2009. The influence of heating and hot water system on the energy performance of a building. Rynek Energii 6, 46-54.

Życzyńska, A., Suchorab, Z., Kočí, J., Černý, R., 2020a. Energy Effects of Retrofitting the Educational Facilities Located in South-Eastern Poland. Energies 13, 2449. https://doi.org/10.3390/ en13102449
Życzyńska, A., Suchorab, Z., Majerek, D., 2020b. Influence of Thermal Retrofitting on Annual Energy Demand for Heating in Multi-Family Buildings. Energies 13, 4625. https://doi. org/10.3390/en13184625

Regulations of the Ministry of Infrastructure of Nov. 6, 2008 amending the regulations on the technical conditions to be met by buildings and their locations. Dz.U. 2008 No. 201 p. 1238. http://isap. sejm.gov.pl/isap.nsf/DocDetails.xsp?id=WDU20082011238

Regulations of The Polish Ministry of Infrastructure of 17 March 2009 concerning the scope and form of the energy audit and the repair audit, design audit cards, as well as algorithms for assessing the profitability of thermo-modernization project. Dz.U. 2009 No. 43 P. 347. http://isap.sejm.gov.pl/isap.nsf/download.xsp/ WDU20090430347/O/D20090347.pdf

Regulations of the Polish Ministry of Transport, Construction and Maritime Economy of 3 Jan. 2013, amending the ordinance on the methodology for calculating the energy performance of a building and a dwelling or a part of a building constituting an independent technical and operational unit, and the method of drawing up and specimen energy performance certificates. Dz.U. 2013 p. 45. http://isap.sejm.gov.pl/isap.nsf/DocDetails. xsp?id=WDU20130000045

Regulations of the Polish Ministry of Transport, Construction and Maritime Economy of 5 July 2013, amending the regulations on the technical conditions to be met by buildings and their location. Dz.U. 2013 p. 926. http://isap.sejm.gov.pl/isap.nsf/DocDetails. $\mathrm{xsp}$ ?id=WDU2013000092.

Regulations of The Polish Ministry of Infrastructure of 27 Feb. 2015 concerning the methodology for calculating the energy performance of a building or part of a building and the preparation of certificates of energy performance. Dz.U. 2015 p. 376. http:// isap.sejm.gov.pl/isap.nsf/download.xsp/WDU20150000376/O/ D20150376.pdf

Regulations of The Polish Ministry of Infrastructure of 20 Dec. 2016 amending the ordinance on the methodology for calculating the energy performance of a building and a dwelling or a part of a building constituting an independent technical and operational unit, and the method of drawing up specimen energy performance certificates. Dz.U. 2017 p. 22. http://isap.sejm.gov.pl/isap.nsf/ DocDetails.xsp?id=WDU20170000022

Regulations of The Czech Ministry of Industry and Trade of 1 Sept. 2020 amending the Ordinance No. 264/2020 Coll. on the energy performance of buildings. Prague: Ministry of Industry and Trade. URL: https://www.zakonyprolidi.cz/cs/2020-264

Regulations of 1 Jan. 2001 amending Act No. 406/2000 on Energy Management. Resolution of the Parliament of the Czech Republic. URL: https://www.zakonyprolidi.cz/cs/2000-406

Regulations of 1 July 2013 amending Act. No. 300/2012 Coll. of amending and supplementing Act No. 555/2005 Coll. on the energy performance of buildings and on the amendment of certain laws as amended. Resolution of the National Council of the Slovak Republic. URL: https://www.slov-lex.sk/pravne-predpisy/ SK/ZZ/2019/378/; URL: https://www.slov-lex.sk/pravne-predpisy/SK/ZZ/2012/300/ 
Regulations of Ministry of Transport and Construction of the Slovak Republic of 10 Mar. 2020 amending Ordinance No. 364/2012 Coll. implementing Act No. 555/2005 Coll. on the energy performance of buildings and on the amendment of certain laws as amended. URL: https:/www.slov-lex.sk/pravne-predpisy/SK/ ZZ/2012/364

Concerted Action EPBD, 2016 - Implementing the Energy Performance of Buildings Directive (EPBD) - Featuring Country Reports, ADENE, 2015, p. 594, ISBN: 978-972-8646-32-5.

Energy Requirements of BR18 A quick guide for the construction industry on the Danish Building Regulations 2018, Danish Knowledge Centre for Energy Savings in Buildings, April, 2018 